\author{
A.B. Tateyeva ${ }^{1}$, M.I. Baikenov ${ }^{1}$, V.I. Parafilov ${ }^{2}$, Ye.N. Martynova ${ }^{2}$, \\ S.K. Mukhametzhanova ${ }^{1}$, D.Ye. Aitbekova ${ }^{1}$ \\ ${ }^{I}$ Ye.A. Buketov Karaganda State University, Kazakhstan; \\ ${ }^{2} J S C «$ ShubarkolKomir», Karaganda, Kazakhstan \\ (E-mail: almatateeva@mail.ru)
}

\title{
Researching of physicochemical properties of the special coke of «ShubarkolKomir» JSC
}

\begin{abstract}
One of the priority directions in the Republic of Kazakhstan is the production of low-sulfur coke with sulfur content up to $1 \%$ and needle coke used in the electrode industry, which is fully purchased by import. Needle coke is used to produce high-quality graphite electrodes needed for the steel industry. Electrodes should have high mechanical strength, electrical conductivity, and low sulfur content. The primary raw material for obtaining diesel fuel and needle coke is the primary coal tar produced at ShubarkolKomir JSC. At present, the obtained products are not processed into valuable chemical substances and motor fuels on the territory of the Republic of Kazakhstan. The physicochemical properties of trademarks $0-10,10-25,25-40,0-60,10-60$, 0-25 mm produced at ShubarkolKomir JSC have been investigated: coke properties by particle size classes - elemental composition of organic part and ash residue, coke ash, specific and apparent density of the samples, porosity of coke samples with subdivision into macro-, meso- and micropores. The chemical composition of coke is determined by technical analysis (moisture, ash content, sulfur content, phosphorus content, volatile matter yield) and elemental analysis (carbon, hydrogen, oxygen, nitrogen, etc.) content.
\end{abstract}

Keywords: special coke, needle coke, moisture, porosity, ash content, density, elemental composition, Shubarkol.

\section{Introduction}

Coal coke is used for smelting cast iron (blast-furnace coke) as a high-quality smokeless fuel, a reducing agent for iron ore, and a leavening agent for charge materials. It is used in the same way as varanaceous fuel in foundry production (foundry coke), for household purposes (household coke), in chemical and ferroalloy industries (special types of coke) [1].

The objects of research are special cokes of trademarks $0-10,10-25,25-40,0-60,10-60,0-25 \mathrm{~mm}$ produced at ShubarkolKomir JSC. The coking temperature is $750-780{ }^{\circ} \mathrm{C}$.

The physicochemical properties of coke are determined by its structure, which is close to the hexagonal layered structure of graphite. The structure of coke is characterized by incomplete orderliness, namely, individual fragments (layers) connected by the Vander-Waals forces, statistically occupy several possible positions (for example, superimposed one on another). Along with the carbon atoms in the spatial lattice of coke heteroatoms $(\mathrm{S}, \mathrm{N}$, and $\mathrm{O})$ can be located, especially in its peripheral part.

The structure and properties of coke depend on the composition of the coal charge, the final temperature and the heating rate of the coked mass. With increasing content of gas coals and other coals characterized by a low degree of metamorphism in the charge, decreasing of the final coking temperature and exposure at this temperature, the reactivity and combustibility of the resulting coke increase. When the content of gas coals in the charge increases, the strength and average size of the pieces of coke decrease, and its porosity increases. Increasing the final coking temperature helps increase the strength of coke, especially to attrition. With an extension of the coking period and a decrease in the heating rate of the coked mass, the average particle size of the coke increases [1].

\section{Experimental}

The chemical composition of the coke deposited on the catalyst is determined primarily by the mechanism of its formation. Today two mechanisms are distinguished, namely, consecutive and carbide cycle. According to the consecutive scheme, coke deposits on the surface of the catalyst are formed as a result of sequential reactions of irregular condensation and polymerization of hydrocarbons accompanied by the formation and binding of cyclic structures. At the same time, their gradual depletion with hydrogen is observed up to the pseudo-graphite structure due to the liberation of light hydrocarbons and hydrogen. Coke in this case is a mixture of high-molecular seal products from resins and asphaltenes to carboides and in the extreme 
case to graphite-like deposits. The true chemical composition of such a mixture is almost impossible to determine, therefore the composition of coke is usually characterized by averaged elemental composition [2]. The chemical composition of coke is characterized by the mass fraction of various elements in the organic matter and the content of mineral impurities.

It is sometimes assumed that the mechanism of coke formation is due to direct thermal decomposition of hydrocarbons. This scheme is realized at high temperatures, but the properties and activity of the catalyst do not play a decisive role, because of the catalyst does not participate in any acts of formation of intermediate compounds. At the same time, the chemical composition of coke -the content of ash, more sulfur content, and in some cases phosphorus content affects the results of blast furnace smelting. The chemical composition of coke is determined by technical analysis (moisture, ash content, sulfur content, phosphorus content, volatile matter yield) and elemental analysis (carbon, hydrogen, oxygen, nitrogen, etc.) content [3].

\section{Results and Discussion}

Methods are known for determining the chemical composition of cokes, calcined in a nitrogen atmosphere for 3 hours in the range of $400-2400{ }^{\circ} \mathrm{C}$. The percentage of carbon, hydrogen, oxygen, sulfur and ash was determined in each sample. The samples studied have different contents of these substances, and their graphite formation proceeds in different ways. The authors note that the oxygen, nitrogen and sulfur atoms are the most strongly retained heteroatoms, and sulfur remains even after treatment at temperatures above $2273 \mathrm{~K}$. However, the number of heteroatoms remains in the material after heat treatment (although this issue is also very important in the case of obtaining pure carbonaceous materials) is not so important, as the effect they had on the kinetics of coke formation.

The quality of coke is one of the decisive factors determining the technical and economic parameters of blast furnace smelting; it depends on the strength, porosity and chemical composition of coke. Some physicochemical parameters of Shubarkol coke samples from the quality certificate of coke by the size classes are shown in Tables 1 and 2.

Table 1

Physicochemical parameters of Shubarkol coke samples (from the quality certificate of coke)

\begin{tabular}{|c|c|c|c|c|c|}
\hline Sample & Coarsenes, $\mathrm{mm}$ & Moisture, \% & $\begin{array}{c}\text { The yield of volatiles } \\
\text { substances, } \%\end{array}$ & Sulfur, \% & $\begin{array}{c}\text { Heat of combus- } \\
\text { tion, kcal/kg }\end{array}$ \\
\hline 5068 & $0-10$ & 19.9 & 11.6 & 0.44 & $7874 / 5665$ \\
\hline 5069 & $10-25$ & 18.8 & 5.4 & 0.31 & $7793 / 5746$ \\
\hline 5070 & $25-40$ & 16.8 & 3.9 & 0.32 & $7228 / 5158$ \\
\hline 5071 & $0-60$ & 16.8 & 6.9 & 0.38 & $7714 / 5702$ \\
\hline 5072 & $10-60$ & 18.9 & 4.1 & 0.34 & $7445 / 5246$ \\
\hline 5102 & $0-25$ & 18.0 & 2.9 & 0.33 & $7805 / 5799$ \\
\hline
\end{tabular}

Ta b l e 2

Technical analysis and elemental composition of Shubarkol coke samples

\begin{tabular}{|c|c|c|c|c|c|c|c|c|c|c|}
\hline No. & Coarseness, mm & $\begin{array}{c}\text { Coarsenes, } \\
\mathrm{mm}(\text { sample) }\end{array}$ & $\mathrm{W}^{\mathrm{a}}, \%$ & $\mathrm{~A}^{\mathrm{a}}, \%$ & $\mathrm{~A}^{\mathrm{d}}, \%$ & $\mathrm{~S}^{\mathrm{d}}, \%$ & $\mathrm{~N}^{\mathrm{d}}, \%$ & $\mathrm{H}^{\mathrm{d}}, \%$ & $\mathrm{C}^{\mathrm{d}}, \%$ & $\mathrm{O}^{\mathrm{d}}, \%$ \\
\hline 5068 & $0-10$ & $<0.1$ & 6.34 & 4.03 & 4.30 & 0.30 & 0.29 & 1.69 & 85.48 & 7.94 \\
\hline 5069 & $10-25$ & $<0.1$ & 5.51 & 3.57 & 3.77 & 0.23 & 0.39 & 2.04 & 87.45 & 6.12 \\
\hline 5070 & $25-40$ & $<0.1$ & 5.34 & 2.85 & 3.23 & 0.32 & 0.42 & 1.87 & 88.31 & 6.72 \\
\hline 5071 & $0-60$ & $<0.1$ & 5.87 & 3.24 & 2.57 & 0.38 & 0.37 & 1.57 & 89.22 & 6.57 \\
\hline 5072 & $10-60$ & $<0.1$ & 6.04 & 1.68 & 1.78 & 0.31 & 0.46 & 1.05 & 93.10 & 3.30 \\
\hline 5102 & $0-25$ & $<0.1$ & 5.75 & 2.65 & 2.81 & 0.27 & 0.43 & 1.52 & 89.81 & 5.16 \\
\hline
\end{tabular}

Indicators of the chemical composition of coke (the content of volatile substances, ash, sulfur, metals and water) practically do not change during processing and transportation. The most important of them when considering the patterns of oxidative regeneration are the chemical composition of coke, its structure and dispersity, as well as the distribution of deposits along the catalyst pellet. At the same time, the results of 
blast furnace smelting are affected by the chemical composition of coke - the ash content, more important is the content of sulfur, and in some cases of phosphorus [4].

Elemental composition of samples of Shubarkol coke was determined in accordance with State Standard 2408-95. Moisture was determined in accordance with with State Standard 11014-2001, ash — according to with State Standard 1171-2012. Elemental composition can be attributed in the group of coke quality indicators, although it does not play a significant role in the assessment of coke, since it is not subject to fluctuations in different cokes. It is usually determined only when compiling the mass balances of the blast furnace operation.

Coke ash. The ash content of the fuel was determined in the laboratories by calcining a sample of finely crushed fuel weighing 1-2 g in porcelain crucibles, and in contrast to determining the yield of volatiles in this case, it is necessary to ensure the presence of oxygen during the calcination process in order to avoid partial coking of the sample. The difference in weight before and after calcination is equal to the ash content of the fuel. It is necessary to note some conventionality of this characteristic of ash content, since chemical reactions occur between the individual mineral impurities in the ash during the ashing process, and in these reactions, for example, ash can become heavier, since the newly formed compounds will contain oxygen from the surrounding air or part of elements will evaporate, etc. Therefore, in order to obtain comparable characteristics by ash content, the process of obtaining ash must be carried out in strictly standard conditions. An open porcelain cup is placed in an electric muffle, where mineral fuel is calcined at a temperature of $800{ }^{\circ} \mathrm{C}$, and fuel oil, wood and vegetable waste at $500{ }^{\circ} \mathrm{C}$. Ashing is carried out slowly, for 2 hours, and without the appearance of a flame.

Laboratory and true ash contents of the shale samples have large discrepancies. Calcium and magnesium carbonates $\left(\mathrm{CaCO}_{3}, \mathrm{MgCO}_{3}\right)$ decompose on heating with the formation of $\mathrm{CO}_{2}$, as a result of which the weight of laboratory ash decreases sharply. For this fuel, the laboratory gives an amendment for the decomposition of carbonates to obtained ash content.

Ash balances are often made in thermotechnical analysis. The amount of ash discharged into the boiler flues and the chimney is determined by weighing the amount of ash remaining on the grate and in the ashtray and knowing the ash weight per $1 \mathrm{~kg}$ of burnt fuel from the fuel analysis. There may be mistakes. Chemical reactions occur in the ash during the calcination, and it has the ability to release volatiles, the volatilization increases with increasing temperature. The weight of laboratory ash is greater than in the furnace, because of the temperature of slagging in the furnace exceeds $1000{ }^{\circ} \mathrm{C}$ and laboratory ash and slag is formed at temperature of $800^{\circ} \mathrm{C}$. In particular, these discrepancies can reach large values in brown coal and shale, the ash of which contains a significant amount of calcium and sulfur.

The ash and slags of the fuel combusted on the grate, in most cases melts, then as it drips down and away from the high temperature zone it cools, hardens and forms quite porous slags. Sometimes ash and slag are so fusible that they do not harden even after leaving the high temperature zone; then this paste-like mass, clogging openings in the grate, serving for the passage of air, increases the gas resistance to the furnace, envelops part of the fuel pieces and makes them difficult to combust. In addition, the low-melting slag is difficult to remove from the furnace without taking up the burning coal at the same time. In cases where the design of the boiler and the furnace does not take into account the fusibility of the slag, the molten mass of the ash can block the passage of gases between the tubes of the boiler at the combustion of pulverized fuel; it grows over the furnace space in the form of stalactites, the removal of which involves considerable difficulties. The brickwork of the furnace is often broken and destroyed during breaking off the boiling slag. The adhesion of the molten slag masses to the brick firing of the furnace usually causes deterioration in the operation of the furnace and the need for more frequent repairs. The destruction of the brickwork is also possible due to the chemical action of hot slag. Such slagging occurred places are protected by surfaces cooled by water (screens), in the process of which the adhesion of slag decreases.

In the laboratory study of ash for fusibility a number of pyramids $20 \mathrm{~mm}$ high with a side of the base of $7 \mathrm{~mm}$ are placed in a special electric furnace. One of the faces of the pyramid must be perpendicular to the base. In the laboratory studies of ash for fusibility slagging occurs in a semi-reducing gas medium at the combustion of the solid lump fuel, therefore, the medium, in which the cone formed from the ash is melted, is composed of gases consisting mainly of $\mathrm{CO}, \mathrm{CH}_{4}, \mathrm{H}_{2}$, with no oxygen [5].

The ash of Shubarkol coke samples is determined according to with State Standard 1171-2012. The melting point of the ash of Shubarkol coke samples was determined in PM-14M1P-TD furnace. Ash content and chemical composition of coke ash are given in the Table 3. 
Melting points and chemical composition of Shubarkol coke ash

\begin{tabular}{|c|c|c|c|c|c|c|c|c|c|}
\hline \multirow{2}{*}{ No. } & \multirow{2}{*}{$\begin{array}{c}\text { Coarseness, } \\
\mathrm{mm}\end{array}$} & \multirow{2}{*}{$\begin{array}{c}\text { Coarsenes, } \\
\text { mm (sample) }\end{array}$} & \multirow{2}{*}{$\begin{array}{l}\text { Melting points } \\
\text { of the ash, }{ }^{\circ} \mathrm{C}\end{array}$} & \multirow{2}{*}{ Ash content, $\%$} & \multicolumn{5}{|c|}{ Chemical composition of the ash, $\%$} \\
\hline & & & & & $\mathrm{SiO}_{2}$ & $\mathrm{Fe}_{2} \mathrm{O}_{3}$ & $\mathrm{CaO}$ & $\mathrm{MgO}$ & $\mathrm{Al}_{2} \mathrm{O}_{3}$ \\
\hline 5068 & $0-10$ & $<0.1$ & 1068 & 4.30 & 1.2 & 11.4 & 11.2 & 3.0 & 1.1 \\
\hline 5069 & $10-25$ & $<0.1$ & 1055 & 3.77 & 1.15 & 10.6 & 10.3 & 1.8 & 1.3 \\
\hline 5070 & $25-40$ & $<0.1$ & 1045 & 3.23 & 2.1 & 11.8 & 11.5 & 2.5 & 1.4 \\
\hline 5071 & $0-60$ & $<0.1$ & 1074 & 2.57 & 1.3 & 11.1 & 11.6 & 2.5 & 1.1 \\
\hline 5072 & $10-60$ & $<0.1$ & 1057 & 1.78 & 1.1 & 10.3 & 11.1 & 1.7 & 1.0 \\
\hline 5102 & $0-25$ & $<0.1$ & 1075 & 2.81 & 1.6 & 11.5 & 10.5 & 2.2 & 1.25 \\
\hline
\end{tabular}

The coke ash depending on the composition can have different catalytic effect on the course of reactions. The coke ash should remain in the form of fairly large pieces. Coke ash, alone and in mixture with impurities that consists of phosphoric anhydrides, increases the elasticity of the joint decomposition of these salts. The silicon compounds contained in the coke ash are converted to water-soluble silicates by fusion with soda, after which silicon is separated from the solution as $\mathrm{SiO}_{2}$ by evaporation with hydrochloric acid. Significant amounts of $\mathrm{SiO}_{2}$ are contained in an empty rock ore, agglomerate compounds and in coke ashes.

Density of coke. There are three types of coke densities, namely, true, apparent and bulk densities. The true density is also called pycnometric or real. The true density is the ratio of the mass of coke deprived of pores to unit volume. To determine the true density of coke, it is necessary to undergo fine grinding, but even in this case the smallest pores remain in the coke particles. The true density is determined by the pycnometric method and this is the most accurate and available in the production conditions.

The true density of coke is dependent on the calcination temperature and the duration of isothermal exposure. It is found that it is possible to obtain coke of different true densities by changing the holding time at a constant calcination temperature. The true density is a measure of needle coke quality. There should be $98.5-99.5 \%$ of the calcined needle coke mass with a density of $2140 \mathrm{~kg} / \mathrm{m}^{3}$. Specific density of samples of Shubarkol's coke was determined by pycnometric method. The apparent density was determined by immersion in a glycerin medium (Table 4 ).

Ta b le 4

Indicators of the density of Shubarkol coke samples

\begin{tabular}{|c|c|c|c|}
\hline Sample & Coarseness, $\mathrm{mm}$ & Specific density, $\mathrm{g} / \mathrm{cm}^{3}$ & Apparent density, $\mathrm{g} / \mathrm{cm}^{3}$ \\
\hline 5068 & $0-10$ & $0.49-0.51$ & $0.45-0.47$ \\
\hline 5069 & $10-25$ & $0.48-0.50$ & $0.46-0.47$ \\
\hline 5070 & $25-40$ & $0.47-0.49$ & $0.45-0.46$ \\
\hline 5071 & $0-60$ & $0.46-0.48$ & $0.44-0.45$ \\
\hline 5072 & $10-60$ & $0.47-0.48$ & $0.41-0.43$ \\
\hline 5102 & $0-25$ & $0.44-0.45$ & $0.23-0.35$ \\
\hline
\end{tabular}

The apparent density is the ratio of the porous material mass to its unit volume. It is the density of coke in the reaction apparatus, apparent density is always less than the true one. There are methods of determining the apparent density of coke by immersion in medium, which does not penetrate into the pores (glycerin or a solid powder). The denser the coke is, the higher its mechanical strength is. The apparent density increases to the temperature of $1100-1200^{\circ} \mathrm{C}$ and then begins to decrease.

Porosity. Mercury porometry is one of the main methods currently used to study the porous structure of materials; this method can be used to determine the size and number of pores, the absolute density of materials, the specific surface area and the pore size distribution. In addition, knowing the shape of the hysteresis loop, you can qualitatively judge the shape of pores.

In 1921, Washburn proposed an equation describing the relationship between the capillary radius and the pressure at which the hollow capillary is filled with mercury

$$
r=-\frac{2 \sigma \cos \theta}{p}
$$

where $\sigma-$ is surface tension of mercury; $\theta-$ is contact angle of mercury; $P$ - is hydraulic pressure. 
In fact, The Washburn equation is the theoretical basis of the mercury porometry method. Coke has a multi-dispersed porous structure. Porosity of coke samples of «ShubarkolKomir» JSC is presented in Table 5 .

Porosity of samples of Shubarkol coke

\begin{tabular}{|c|c|c|c|c|c|c|}
\hline Sample & $\begin{array}{c}\text { Coarseness, } \\
\mathrm{mm}\end{array}$ & $\begin{array}{c}\text { Density coke, } \\
\mathrm{g} / \mathrm{cm}^{3}\end{array}$ & $\begin{array}{c}\text { Total pore vol- } \\
\mathrm{ume}, \mathrm{g} / \mathrm{cm}^{3}\end{array}$ & Macropores, $\mathrm{g} / \mathrm{cm}^{3}$ & Mesopores, $\mathrm{g} / \mathrm{cm}^{3}$ & $\begin{array}{c}\text { Micropores, } \\
\mathrm{g} / \mathrm{cm}^{3}\end{array}$ \\
\hline 5068 & $0-10$ & 0.98 & $0.4-0.6$ & $0.6-0.8$ & $0.2-0.25$ & $0.1-0.2$ \\
\hline 5069 & $10-25$ & 0.85 & $0.4-0.5$ & $0.7-0.8$ & $0.2-0.28$ & $0.09-0.2$ \\
\hline 5070 & $25-40$ & 0.74 & $0.3-0.5$ & $0.6-0.7$ & $0.18-0.25$ & $0.1-0.3$ \\
\hline 5071 & $0-60$ & 0.87 & $0.4-0.5$ & $0.6-0.8$ & $0.23-0.3$ & $0.2-0.28$ \\
\hline 5072 & $10-60$ & 0.97 & $0.5-0.6$ & $0.8-0.9$ & $0.25-0.3$ & $0.1-0.2$ \\
\hline 5102 & $0-25$ & 0.78 & $0.3-0.5$ & $0.7-0.9$ & $0.15-0.2$ & $0.1-0.15$ \\
\hline
\end{tabular}

We have used modern mercury porosimeters system PASCAL (PASCAL 140/440). These are automatic devices for preparing samples for porosimeteric analysis and measuring its porosity in the range from $0.1-$ $0.8 \mathrm{~g} / \mathrm{cm}^{3}$. Small volumes $\left(0.4 \mathrm{~mm}^{3}\right)$ of the sample are used for the analysis, and the sample must have a strong enough skeleton to withstand the pressure. The sample is placed in a specially prepared glass dilatometer, which is placed in the holder. Then the air is pumped out of the system until the vacuum $0.1 \mathrm{~Pa}$ is reached. When vacuum is reached in the system, the process of pumping mercury into the open pores of the sample begins. The volume of pressed mercury is fixed by the sensor. When the set pressure is reached, the system automatically stops and mercury is discharged. At this point, a hysteresis loop is formed, the shape of which is indirectly possible to estimate the shape of the pores. The pressure drops to atmospheric pressure, the system stops and the experiment is over. The time of the experiment depends on the porous structure of the sample, an average of 3-4 hours, not counting the preparatory work.

\section{Conclusions}

The physical and mechanical properties of trademarks $0-10,10-25,25-40,0-60,10-60,0-25 \mathrm{~mm}$ produced at «ShubarkolKomir» JSC have been investigated, namely, coke properties by particle size classes - elemental composition of organic part and ash residue, coke ash, specific and apparent density of the samples, porosity of coke samples with subdivision into macro-, meso- and micropores.

\section{References}

1 Капустин В.М. Технология переработки нефти / В.М. Капустин. - Алматы: Эпиграф, 2016. — 66 с.

2 Хайрудинов И.Р. Перспективы развития ресурсной базы для получения игольчатого кокса / И.Р. Хайрудинов, А.А. Тихонов, М.М. Ахмедов // Химический журнал Башкирии. - 2011. — № 3. - С. 103-111.

3 Агроскин А.А. Теплофизические свойства каменноугольного кокса / А.А. Агроскин // Кокс и химия. - 1980. - № 2. - C. 8-15.

4 Степанов Е.Н. Методы определения качества кокса и их сравнительная оценка / Е.Н. Степанов, Д.А. Мезин, О.В. Чуйкина, Л.В. Шебунова // Кокс и химия. - 2011. — № 12. - С. 24-26.

5 Wood J. Effect of Coke Deposition upon Pore Structure and Selfdiffusion in Deactivated Industrial Hydroprocessing Catalysts / J. Wood, L.F. Gladden // Applied Catalysis. — 2003. — A. — P. 241-253.

А.Б. Татеева, М.И. Байкенов, В.И. Парафилов, Е.Н. Мартынова, С.К. Мухаметжанова, Д.Е. Айтбекова

\section{«Шұбаркөлкөмір» АҚ коксының физика-химиялық қасиеттерін зерттеу}

Қазақстан Республикасында өндірістік басым бағыттардың бірі құрамында күкірт 1 \%-ға дейін болатын аз күкіртті кокстың және электрод өнеркәсібінде қолданылатын, елімізде толықтай импортпен сатып алынатын инелі кокстың өндірісі болып табылады. Болат өнеркәсібіне қажет жоғары сапалы графит электродтарын өндіру үшін инелі коксты қолданылады. Электродтар жоғары механикалық беріктікке, электрөткізгіштікке, күкірттің аз мөлшеріне және төмен термиялық кеңею коэффициентіне 
ие болуы тиіс. Дизель отынын және инелі кокс өндіру үшін бастапқы шикізат ретінде «Шұбаркөлкөмір» АҚ өндірілген біріншілік таскөмір шайырлары есептеледі. Қазіргі уақытта алынатын өнімдер Қазақстан Республикасында бағалы химиялық заттар мен мотор отынына қайта өңделмейді. Мақаладағы зерттеу нысаны - «Шұбаркөлкөмір» АҚ өндірілген 0-10, 10-25, 25-40, 0 $60,10-60,0-25$ мм өлшемді сауда белгілерінің арнайы кокстары. Әр өлшемнің физикалық және химиялық қасиеттері - органикалық бөлік пен күлді қалдықтың элементтік құрамы, кокс күлі, үлгілердің меншікті және байқалатын тығыздықтары, кокс үлгілерінің кеуектілігі макро-, мезо- және микрокеуектілікке жіктеліп, анықталды. Кокстың химиялық құрамы техникалық талдаумен (ылғалдылық, күлділік, күкірттің мөлшері, фосфор мөлшері, ұшқыш заттардың шығымы) және элементтік талдаумен (көміртек, сутек, оттек, азот және т.б.) анықталды.

Кілт сөздер: арнайы кокс, инелі кокс, ылғалдылық, кеуектілік, күл, тығыздық, элементтік құрам, Шұбаркөл.

\title{
А.Б. Татеева, М.И. Байкенов, В.И. Парафилов, Е.Н. Мартынова, С.К. Мухаметжанова, Д.Е. Айтбекова \\ Исследование физико-химических свойств спецкокса АО «Шубарколькомир»
}

\begin{abstract}
Одним из приоритетных направлений в Республике Казахстан является производство малосернистого кокса с содержанием серы до 1 \% и игольчатого кокса, используемого в электродной отрасли, который в полном объеме закупается по импорту. Игольчатый кокс используется для получения высококачественных графитовых электродов, необходимых для сталелитейной промышленности. Электроды должны иметь высокую механическую прочность, электропроводность, низкое содержание серы и низкий коэффициент термического расширения. Исходным сырьем для получения дизельного топлива и игольчатого кокса является первичная каменноугольная смола АО «Шубарколькомир». В настоящее время получаемая продукция не перерабатывается в ценные химические вещества и моторные топлива на территории Республики Казахстан. Исследованы физико-химические свойства спецкоксов товарных марок 0-10, 10-25, 25-40, 0-60, 10-60, 0-25 мм, производимых на АО «Шубарколькомир»: свойства кокса по классам крупности - элементный состав органической части и зольного остатка, зола кокса, удельная и кажущаяся плотность проб, пористость проб кокса с подразделением на макро-, мезо- и микропоры. Химический состав кокса определялся техническим анализом (влажность, зольность, содержание серы, содержание фосфора, выход летучих веществ) и элементным анализом (углерод, водород, кислород, азот и др.).
\end{abstract}

Ключевые слова: спецкокс, игольчатый кокс, влажность, пористость, зольность, плотность, элементный состав, Шубарколь.

\section{References}

1 Kapustin, V.M. (2016). Tekhnolohiia pererabotki nefti [Oil Refining Technology]. Almaty: Epihraph [in Russian].

2 Khairudinov, I.R., Tikhonov, A.A. \& Akhmedov, M.M. (2011). Perspectivy razvitiia resursnoi bazy dlia polucheniia iholchatoho koksa [The Prospect of Expanding the Resource Base for Obtaining Needle Coke]. Khimicheskii zhurnal Bashkirii Chemical Journal of Bashkiria, 3, 103-111 [in Russian].

3 Agroskin, A.A. (1980). Teplofizicheskie svoistva kamennouholnoho koksa [Thermophysical Properties of Carboniferous Coke]. Koks $i$ khimiia - Coke and Chemistry, 2, 8-15 [in Russian].

4 Stepanov, E.N., Mezin, D.A., Chuikina, O.V., \& Shebunova, L.V. (2011). Metody opredeleniia kachestva koksa i ikh sravnitelnaia otsenka [Methods of Determining of Coke Quality and Their Comparative Evaluation]. Koks $i$ khimiia - Coke and Chemistry, 12, 24-26 [in Russian].

5 Wood, J., \& Gladden, L.F. (2003). Effect of Coke Deposition upon Pore Structure and Self diffusion in Deactivated Industrial Hydroprocessing Catalysts. Applied Catalysis, A, 241-253. 